\title{
Hot ethanol extraction: economic feasibility of a new and green process
}

\author{
Patrick Carré $^{1, *}$, Morgane Citeau ${ }^{1}$ and Sylvie Dauguet ${ }^{2}$ \\ ${ }^{1}$ OLEAD, 11 rue Gaspard-Monge, 33610 Canéjan, France \\ 2 Terres Inovia, 11 rue Gaspard-Monge, 33610 Canéjan, France
}

Received 8 November 2017 - Accepted 31 December 2017

\begin{abstract}
A new extraction process using ethanol at a temperature above boiling point is assessed from an economic point of view. The study was based on an assessment of the main operating costs adjusted by Lang's factor. Operating costs were assessed based on energy consumption calculated using a model of the process developed from experimental results, and for a hypothetical unit with a $160000 \mathrm{t} / \mathrm{year}$ rapeseed crushing capacity. The processing cost was estimated at $47.4 €$ per ton of processed seed. Amortization represented $35 \%$ of this cost, energy $32 \%$ and manpower $10 \%$. Uncertainty about investment is the main factor that could lead to significant error in this cost, but this uncertainty could be offset by an adjustment of the amortization duration, most of the equipment being durable. Profit generated by the process relies principally on a better valuation of the meal: higher value comes from higher protein content and quality on the market for GM-free high protein feedstuffs. Oil quality is also improved by a lower oleic acidity, low phospholipid content and pigment concentration. This gain was estimated at $2.5 \%$ of the crude oil value. Unlike the conventional hexane process, hot ethanol extraction produces molasses in small proportions. Molasses value was set at $70 \%$ of corn price. The process profitability appears sufficiently positive to justify further research to test the hypothesis underlying our model. The main uncertainty lies in the performance of the process in real conditions of counter-flow extraction and solvent regeneration.
\end{abstract}

Keywords: ethanol / extraction / rapeseed / meal / proteins / feasibility / economy / hydrocyclones

Résumé - Extraction à l'éthanol haute température: faisabilité économique d'un nouvel écoprocédé. Un nouveau procédé d'extraction basé sur l'utilisation d'éthanol au-dessus du point d'ébullition est évalué au point de vue économique. L'étude repose sur une évaluation des principaux équipements majorés par le facteur de Lang. Les charges opérationnelles ont été évaluées pour les coûts énergétiques grâce à une modélisation du procédé développée à la suite de résultats expérimentaux pour une unité hypothétique de $160000 \mathrm{t}$ de colza par an. Le coût de trituration a été évalué à $47,4 € / t$ de graine transformée. Les amortissements représentent $35 \%$ de ces coûts, l'énergie $32 \%$ et la main-d'œuvre $10 \%$. L'incertitude à propos des amortissements est le principal risque d'erreur de cette évaluation, toutefois, la prise d'une durée d'amortissement plus longue pourrait compenser cette erreur, la durée de vie des équipements le permettant. La rentabilité du procédé repose principalement sur une meilleure valorisation des tourteaux. Celle-ci est justifiée par une plus forte concentration en protéines ainsi qu'une meilleure qualité de ces dernières. Cela pourrait ouvrir à ce tourteau le marché des protéines non-OGM. La qualité de l'huile est également améliorée par une très faible acidité et de faibles teneurs en phospholipides et pigments. Un gain équivalent à $2,5 \%$ de la valeur de l'huile brute a été pris en compte. À la différence du procédé hexane, le procédé à l'éthanol chaud donne lieu à la production d'une petite quantité de mélasse. Celle-ci est valorisée à $70 \%$ de la valeur du maïs. La rentabilité du procédé paraît suffisante pour justifier de nouvelles études visant à valider les hypothèses qui ont permis de bâtir ce modèle. La plus grande incertitude réside en effet dans les performances du procédé dans des conditions réelles d'extraction à contre-courant et de régénération du solvant.

Mots clés : éthanol / extraction / colza / tourteaux / protéines / faisabilité économique / hydrocyclones

\footnotetext{
*Correspondence: carre@cetiom.fr
} 


\section{Introduction}

The food sector in France is one where consumers are overwhelmingly placing quality before price (Tavoularis et al., 2015). Confidence is a prerequisite that the large retail chains are trying to consolidate by setting requirements for the products they market under their own brands. Similarly, independent-label and controlled-origin products also want stringent specifications to meet consumer expectations (Doyon and Bergeron, 2015). Animal welfare, environmental impact of production and other societal concerns are more and more often included in these requirements. Feeds must meet increasingly stringent specifications, banishing GMOs, and any substances suspected of being harmful to animals and/or consumers. In this sector, competition is also driven by the requirements of the specifications and the level of guarantees given to the consumer. Our assumption is that an offer on this market of hexane-free meal may meet a latent demand, if only because of the growing market share of organic products. Unlike hexane, ethanol is a solvent of agricultural origin and also a food item in the diet of a large part of the population. It is on the list of authorized solvents for the processing of products from organic farming (European Commission Regulation (EC) No. 889/2008), and its image among consumers does not pose any particular problems. Ethanol extraction also matches several of the principles of Green Extraction enumerated by Chemat (Chemat et al., 2012). Beyond avoidance of hexane and more specifically n-hexane, the process respects first and second principles (use of renewable resource / solvents) because of the agricultural origin of the solvent. Energy conservation ( $3 \mathrm{rd}$ principle) is compatible with ethanol extraction because of the non-distillation recovery of the oil fraction provided that best available techniques are also used for the drying operation and proteins desolventization. Coextraction of carbohydrates and oil in the same time is a step in the direction of bio-refinery (4th principle) that could result in further fractionation and valuation of secondary metabolites like sinapine and phospholipids. Robust and simple operation like dephasing the neutral lipids by temperature change and higher purity of the lipids fraction resulting from that method of separation are in accordance with fifth and sixth principles.

The present study set out to evaluate the economic feasibility of a process using ethanol at a temperature higher than boiling point and using a solid/liquid separation in hydrocyclones. This technology has already been proposed by Lars Linnet of Alfa Laval for the extraction of fishmeal (Linnet, 2012). Its main advantage is that it can solubilize more oil in the solvent than at lower temperature, and can recover the oil by cold phase shift. On the other hand, it requires working with a very specific particle size range, which requires grinding in a solvent medium.

This study follows laboratory work modeling the kinetics of extraction and characterizing the products derived from ethanol extraction. A countercurrent extraction model based on these results was developed that enabled us to evaluate the energy flows necessary for the operation of the process. The material balance used here is also derived from the same laboratory-scale study.

\section{Warning}

The objective of this work was to collect the available data and evaluate the hypotheses necessary to develop an estimate of the process costs and to evaluate the feasibility of a hot ethanol extraction process on an industrial scale. With a more complex and constraining process, including the need for preliminary strong drying, desolventization under reduced pressure and managing a third product stream (molasses), our process cannot compete with the regular hexane process without improving the value of resulting proteins and oil. Our work is limited to a proof of concept focused on the sensitive points of the process: we have therefore not studied the valuation of these products. Consequently, the reader is warned that our hypotheses are not based entirely on historical information or scientific evidence, but to some extent on subjective though cautious estimations.

Our previous study produced a numerical model of counter-flow extraction that was used to evaluate capital and operational costs (Turton et al., 2015). In addition, based on oil and meal composition, we undertook the more difficult task of assigning a value to these new products that have no equivalent on the market. Although it was relatively simple to give a value to the higher protein content of the meal, the "hexane-free" property cannot readily be valued. This feature anticipates an expectation of the market, but in the area of defatted meals, in the absence of an actual offer, only a hypothesis is possible. We consider here that a segment of the market is ready to acknowledge that ethanol-extracted meals have an advantage in terms of naturalness over hexane-extracted meals, just as non-GMO soybean meals command a higher price for feeding animals bred under quality labels and produced according to stringent specifications.

\section{Setting up an industrial model}

According to experts, the market in France for our improved meals could absorb the production of a unit processing $160000 \mathrm{t}$ of rapeseed per year. Figure 1 depicts the process.

\subsection{Seed drying}

In the hot ethanol process, it is indispensable that the water content of seeds is reduced to less than 3\% to prevent waterenrichment of the solvent (Hron et al., 1982). Such water gain would result in a decreasing ability of the solvent to dissolve the oil. A very low water content is desirable, but given that oil solubility depends also on temperature, and that solid/liquid separation with hydrocyclones requires a relatively high solvent-to-solid ratio, further drying is not required. A drying device for achieving this level of performance cannot be a conventional seed dryer in which warm air is blown into a bulk of seed, for two reasons: high risk of fire with oilseeds of low water content (Noel and Krapf, 1986) and low energy efficiency when the heat transfer is by heating air and the initial moisture of the seed is already low. However, oil-mills use conditioners where heat transfer is achieved by heating the seeds instead of air, and in which the air mass is driven through 


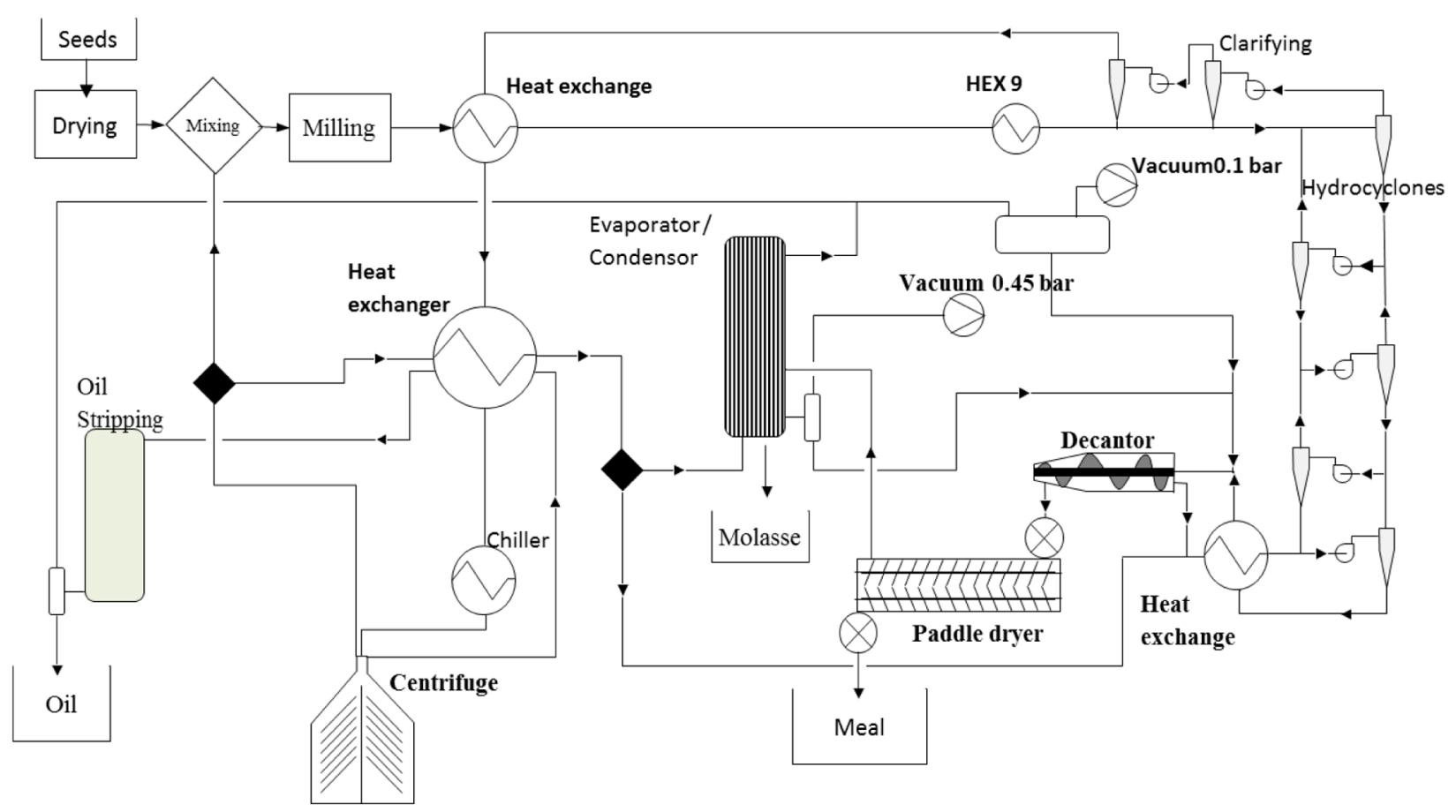

Fig. 1. Process layout.

the seeds to maximize the heat efficiency (Carré, 2012). These devices deploy large exchange surfaces, and we consider that they could be used in a way that combines temperatures not exceeding $70^{\circ} \mathrm{C}$ in the seeds with relatively high heat efficiency.

\subsection{Wet-milling of the seeds in the solvent}

This step is very important since it conditions a good solid/ liquid separation in the hydrocyclones, and determines extraction duration. Our work highlights the negative impact that a small proportion of insufficiently ground particles can have on oil recovery. It is thus necessary to have an efficient device. Experiments carried out with different technologies failed to give the desired quality of milling, so we resorted to a dry milling system that was not entirely satisfactory. However, experts involved in the project estimated that the required particle size profile could be obtained at an industrial scale by including a recycling system to screen out the largest particles and convey them back to the mill.

\subsection{Extraction}

This is carried out at a temperature of $90-95^{\circ} \mathrm{C}$ in a module composed of hydrocyclones functioning in partial counter-flow. This module has five stages of separation and two stages of clarification to remove the solid particles of the miscella. The solvent is mostly a lean miscella resulting from the cold precipitation of neutral lipids. The counter-flow is considered partial because some of the fresh solvent should be introduced with the solid at the wet milling point. The energy cost of raising the suspension temperature to $95^{\circ} \mathrm{C}$ is moderated by heat recovery in exchangers where inflows take heat from outflows

\subsection{Final decantation of the meal}

Hydrocyclones will not work with non-liquid material, so the underflow leaving the extraction has to be mechanically desolventized by a centrifuge decanter. Before this operation, it receives a flow of pure solvent derived from the condensation of the desolventizer and from solvent regeneration.

\subsection{Liquid/liquid separation of miscella}

Solubility of oil in ethanol being temperature-dependent, the miscella is cooled to precipitate the neutral lipids. The temperature in the model was set to $0{ }^{\circ} \mathrm{C}$ to minimize the retention of neutral lipids in the lean miscella. The pour point of rapeseed oil being $-32{ }^{\circ} \mathrm{C}$ (Blin et al., 2013), it should remain sufficiently liquid for a vertical plate centrifuge. A static decantation would be a cheaper alternative for this part of the process, but considering the high flow of miscella, the volume of the decanter could be very large.

\subsection{Meal desolventization}

This operation has to be carried out under reduced pressure to avoid damaging protein. A paddle drier is the solution we advocate. A pressure of 450 mbar corresponding to the boiling point of azeotropic ethanol at $57^{\circ} \mathrm{C}$ was chosen. No direct steam is employed, to prevent enrichment of the solvent in water. In contrast with hexane, the presence of up to $1 \%$ of ethanol residues in the meal can be considered acceptable, since ethanol is miscible in water and the meal 
contains about $10 \%$ of water. This liquid phase is bound to the solid, and this bonding reduces the vapor pressure of ethanol.

\subsection{Partial regeneration of the solvent}

This operation is necessary for the removal of the nonlipids extracted by the hot ethanol. It results in the desolventization of the molasses. We hypothesized that the latent heat of vaporization of the solvent vapors from the paddle drier could be used to evaporate some of the lean miscella. For this purpose, the evaporator would function at 100 mbar and take into account the lower density of the vapor.

\subsection{Oil finishing}

Another evaporator is required to strip the oil from the liquid/liquid decantation, since this phase contains about $10 \%$ of solvent. This operation would be carried out under vacuum, and require a small injection of direct steam.

\subsection{Other}

Utilities and further operations such as molasses finishing and building costs were not studied, but their costs are included in Lang's factor.

\section{Determination of the process costs}

\subsection{Evaluation of the investment}

This study is an approximate approach based on an assessment of the main equipment, to which a multiplying factor is applied to take into account all the costs generated by the installation and commissioning (buildings, utilities, ancillary equipment, structures, piping, storages, studies). Lang's factor is generally 3.6 for complex installations functioning with liquids. A smaller value was retained for the seed drying because it concerns solids, like the desolventization of the meals, the cost including ancillary equipment. Table 1 lists these costs; Table 2 states the origin of the figures.

Building and storage are amortized over 15 years. Financial costs were estimated based on loans with an interest rate of $3 \%$ and a 7 -year repayment period. For manpower, it was considered that the factory would require a staff of 16 persons. The plant would work 8000 hours per year with 5 teams of two, each worker doing 1600 hours per year. Operational teams would include a skilled collaborator and a lower-wage worker. Two supervisors would support these teams and ensure scheduling. The staff also includes a maintenance specialist and a person in charge of logistics and storage. A processing engineer manages the unit, assisted by an

Table 1. Main equipment and costs.

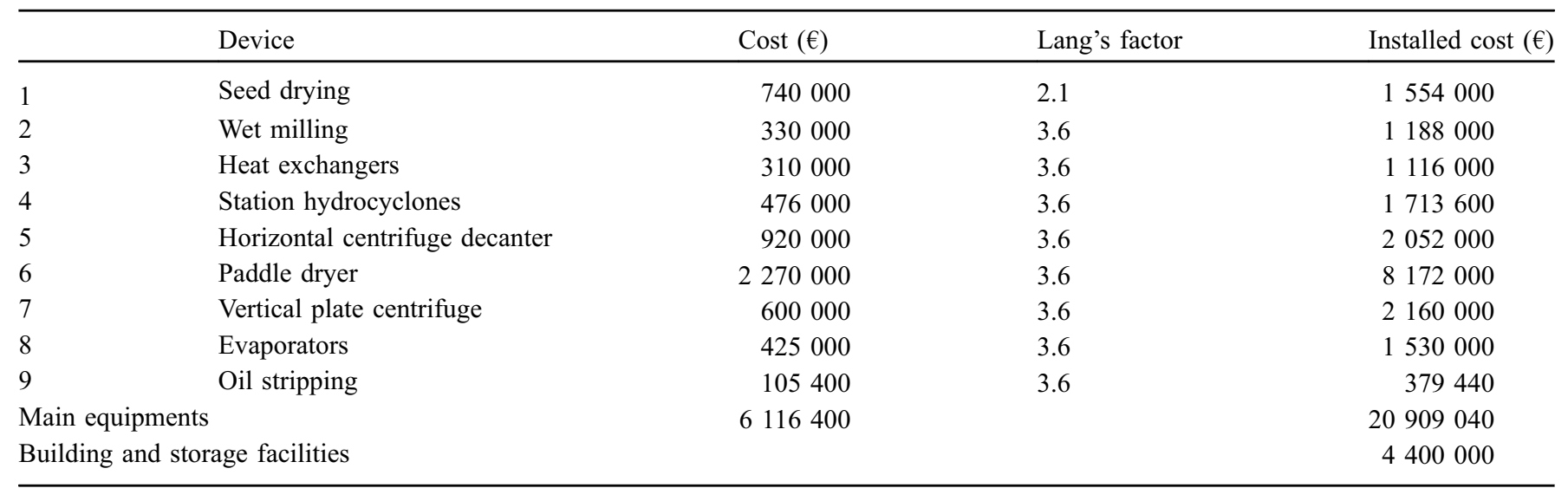

Table 2. Origin of data in Table 1.

\begin{tabular}{ll}
\hline 1 & Based on the price of a stack cooker dimensioned to cook $2.5 \mathrm{t} / \mathrm{h}$ of soybean $(200 \mathrm{k} €)$ up-scaled with the factor $(20 / 2.5)^{0.63}$. \\
$20 \mathrm{t} / \mathrm{h}$ being the capacity of the model \\
Wet milling: budget cost given by a supplier for 3 colloid mills of $55 \mathrm{~kW}(40 \mathrm{~m} 3 / \mathrm{h})$ \\
3 & Heat exchangers: budget given by supplier involved in the study \\
4 & Hydrocyclone skid: budget given by the same supplier \\
5 & Centrifuge decanter: budget given by a supplier for ATEX $800 \mathrm{k} €$. Machine $60 \mathrm{~m} 3 / \mathrm{h}$ extrapolated to $76 \mathrm{~m} 3 / \mathrm{h}\left(\mathrm{X}_{2} / \mathrm{X}_{1}\right)^{0.63}$ \\
6 & Paddle drier: budget given by a supplier including ancillary equipment for the vacuum and condensation of the vapor \\
7 & Vertical plate centrifuge: budget given by a supplier \\
$8 \& 9$ & Evaporators: figures from Loh et al. $(2002)$ corrected by inflation and for stainless steel $(304 \mathrm{~L})$
\end{tabular}

Building and storage: based on a $1000 \mathrm{~m}^{2}$ plant costing $1150 € / \mathrm{m}^{2}+100 \mathrm{~m}^{2}$ for offices and employee accommodation at $2000 € / \mathrm{m}^{2}$. The cost of storage includes a $6000 \mathrm{t}$ silo for seeds, $3600 \mathrm{t}$ for meals, $4000 \mathrm{t}$ for oil and $500 \mathrm{t}$ for molasses. The cost is based on a review of press releases on new storage facilities in France. An average investment of $185 € / t$ was found for the grains. For the liquid storage, the value $(137.5 € / t)$ is from the database of Turton (Turton et al., 2015). The land $\operatorname{cost}\left(5000 \mathrm{~m}^{2}\right.$ ) was estimated based on $38 € / \mathrm{m}^{2}$ according to the average of a sample of offers available on various real estate websites consulted in October 2017 (France). 
administrative agent. Insurance was assessed based on four per thousand of the investment value.

The process modeled to determine the flow of solvent (lean miscella and distilled alcohol) required reaching the low oil residues hypothesized. These flows were computerized for calculation of the heat flow (heat recovery, steam consumption and cooling energy) necessary for the processing. Energy costs were estimated based on the model. Steam kWh cost was estimated at $0.025 €$ according to natural gas prices and treated water costs. Electricity costs were taken from a public database (Pégase) belonging to the French Ministry of the Environment for the consumption bracket of 2 to $20 \mathrm{GWh} / \mathrm{Yr}(86.5 €$ per $\mathrm{MWh}$ ). The financing requirement of the operating cycle corresponds to the remuneration of the fixed assets to ensure operation (seed purchases, wages, etc.). It was estimated at 2 months of operation. The interest rate was set at $90 \%$ of the rate for investment.

Table 3 recapitulates all these costs.

\subsection{Sensitivity to uncertainty}

The principal costs being amortization, steam and workers, Figure 2 presents the effects of varying these factors around the central value. The uncertainty in investment costs is the one with the greatest impact on the processing cost. A 33\% higher investment cost would increase the processing cost by $6.4 € / \mathrm{t}$. The same error in workers costs would lead to a $1.4 € / t$ rise and $2.8 € / \mathrm{t}$ for steam. By its nature, the Lang's factor method is not very accurate; the reader should keep in mind this uncertainty.

\section{Assessment of income}

The main difference between the conventional and ethanol extractions is the production of molasses, mainly composed of non-lipid-soluble material. Molasses results from the partial distillation of the lean miscella. As a result, the meal contains a higher protein content and less oil residue. Molasses also contains lipids, which explains the lower oil yield. These lipids contain phospholipids and free fatty acids, so this loss is offset by a better quality of crude oil. Hence, the crude oil will generate fewer losses at the refining step, and lower consumption of caustic soda, phosphoric acid and bleaching earths. Table 4 presents the avoided costs in oil refining resulting from the ethanol processing. This cost reduction represents $3.2 \%$ of the crude oil cost. We considered that $80 \%$ of that improvement would be reached in operational processing, and a $2.5 \%$ rise of the oil value is taken into account. This assessment is conservative, since the Capex related to neutralization was not considered.

Concerning the meal value, we consider an improvement of the protein content from $33.3 \%$ (Terres Inovia, 2016) to $38.5 \%$ because of the partial extraction of carbohydrates by ethanol. The protein $\mathrm{KOH}$ solubility is on average $46 \%$, versus $80 \%$ in the ethanol process. This should lead to an improvement in protein digestibility, on which no data are available. We nevertheless considered a gain of $7 \%$ in comparison with regular rapeseed meal. Combining the protein concentration and digestibility improvement gives an equivalent meal protein content of $41.2 \%$ (123.8\% of regular meal).

Table 3. Cost assessment.

\begin{tabular}{lrl}
\hline Category & Per year (€/year) & $\begin{array}{l}\text { Per ton of seeds } \\
\text { processed }(€ / \mathrm{t})\end{array}$ \\
\hline Amortization & 2958482 & 16.66 \\
Interest & 697837 & 4.36 \\
Maintenance & 321820 & 2.01 \\
Thermal energy (gas) & 1500000 & 9.38 \\
Electricity & 968800 & 6.06 \\
Workers & 755000 & 4.72 \\
Insurance & 78624 & 0.49 \\
Cash-flow cost & 283089 & 1.77 \\
Other & 320000 & 2.00 \\
Total & 7883652 & 47.44 \\
\hline
\end{tabular}

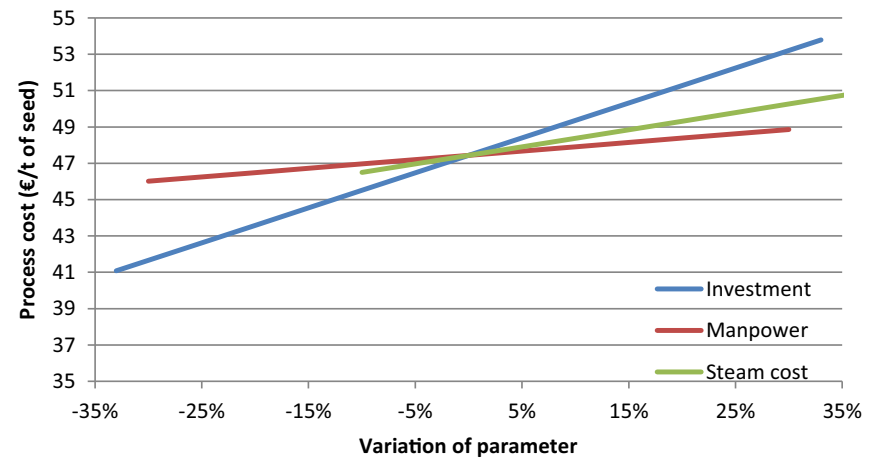

Fig. 2. Sensitivity of processing cost to uncertainty in a selection of parameters.

Table 4. Recapitulation of avoided refining costs (per ton of crude oil).

\begin{tabular}{llcc}
\hline Costs & $\begin{array}{l}\text { Conventional } \\
(\mathrm{kg} / \mathrm{t} \text { crude oil })\end{array}$ & Rate of reduction & $\begin{array}{l}\text { Cost } \\
(€ / \mathrm{kg})\end{array}$ \\
\hline Oil losses & 32 & $80 \%$ & 0.74 \\
$(€ / \mathrm{t})$
\end{tabular}

\footnotetext{
${ }^{*}$ Sneider and Finkbeiner (2013).
} 
We also considered that the unique combination of high protein content, the "hexane-free" character of the meal and its low-fat content could interest the GM-free high protein feedstuffs market. In France, GM-free soybean costs on average 20\% more than the regular meals. Our hypothesis is that the ethanol rapeseed meals are worth $10 \%$ more than their hexane counterparts. By cumulating the concentration effect and access to the high protein GM-free market, we can envisage a $36 \%$ value rise for the ethanol meal.

\subsection{Molasse value}

Assigning a value to the molasses is hard, because there is no equivalent on the market. With $20 \%$ lipids, this material has high energy value. Molasses from the sugar extraction has roughly the same energy content as that from corn. In the case of rapeseed, carbohydrates and lipids are likely to contain large amounts of phenolic compounds, leading to dark coloration and bitterness. It was therefore decided to give the molasses a value equivalent to $70 \%$ of that from corn $(114 € / t)$.

\subsection{Profits}

Based on the above data, we calculated the crushing margins. The gross margin is the difference between the sums of products (material balance per unit value of the products) and the value of the rapeseed (June 2017). We compared the conventional process and the ethanol extraction process. The hexane extraction cost was set at $30 € / \mathrm{t}$ for the comparison. Cheng and Rosentrater (2017) recently modeled the cost of hexane extraction of soybean for different capacities. For units with a capacity of $1 \mathrm{Mt} / \mathrm{year}$, they found a crushing cost of $36.9 \mathrm{\$} / \mathrm{t}$ $(31 € / t)$, which is close to our rough assessment. This cost in reality depends on the mill capacity, the amortization of its equipment, its energy efficiency, etc. Table 5 gives the amount of each product resulting from both processing methods and their valuation. There is an added value of $32 € / t$ of seed for the gross margin, and $14.6 € / \mathrm{t}$ after the processing cost. The calculation shows that the lower oil production is substantially offset by its value improvement. The meal value is responsible for the main added value, with $22 €$ per ton of seeds, whereas the molasses generates only $7.7 €$ per ton of seed (1.5\% of the total).

\subsubsection{Sensitivity to uncertainties in the net margin differential $(\Delta \mathrm{nm})$}

We call net margin differential $(\Delta \mathrm{nm})$, the difference between the crushing margin of the two processes after deducting the processing costs. Figure 3 presents the sensitivity of $\Delta \mathrm{nm}$ to the valuation of the products. For the meal, $0 \%$ on the horizontal axis corresponds to the $36 \%$ of value improvement that we have taken in account, $-100 \%$ on the axis corresponds to a valuation at the level of conventional meal. With oil $-100 \%$, $0 \%$ and $100 \%$ on the horizontal axis correspond respectively to $0,2.5 \%$ and $5 \%$ of value improvement. For molasses, the values range from 0 to $228 € / t$. The valuation of the meal is the key factor in the ethanol extraction process, since $\Delta \mathrm{nm}$ decreases quickly and reaches zero for $-40 \%$, i.e., when the added value falls below $122 \%$ of the conventional meal. This level corresponds to improvement in the protein concentration and digestibility. These estimates give sufficiently solid grounds to assume the
Table 5. Margins of crushing comparison.

\begin{tabular}{|c|c|c|c|c|}
\hline Process & Material & Balance & $\begin{array}{l}\text { Costs } \\
(€ / t)\end{array}$ & $\begin{array}{l}\text { Value for } \\
1 \text { ton of } \\
\text { seed }(€)\end{array}$ \\
\hline \multirow{7}{*}{ Hot ethanol } & Seeds & 100 & 355 & 355.0 \\
\hline & Oil & 43.8 & 763.6 & 334.6 \\
\hline & Meal & 47.7 & 292.4 & 139.4 \\
\hline & Molasses & 6.7 & 114 & 7.7 \\
\hline & Sum products & 98.2 & & 481.7 \\
\hline & \multicolumn{3}{|c|}{ Gross margin of crushing } & 126.7 \\
\hline & \multicolumn{3}{|c|}{ Margin after processing costs (base $47.4 € / \mathrm{t}$ ) } & 79.3 \\
\hline \multirow{6}{*}{ Conventional } & Seeds & 100 & 355 & 355.0 \\
\hline & Oil & 44.6 & 745 & 332.3 \\
\hline & Meal & 54.6 & 215 & 117.4 \\
\hline & Sum products & 99.2 & & 449.7 \\
\hline & \multicolumn{3}{|c|}{ Gross margin of crushing } & 94.66 \\
\hline & \multicolumn{3}{|c|}{ Margin after processing costs (base $30 . € / \mathrm{t}$ ) } & 64.66 \\
\hline
\end{tabular}

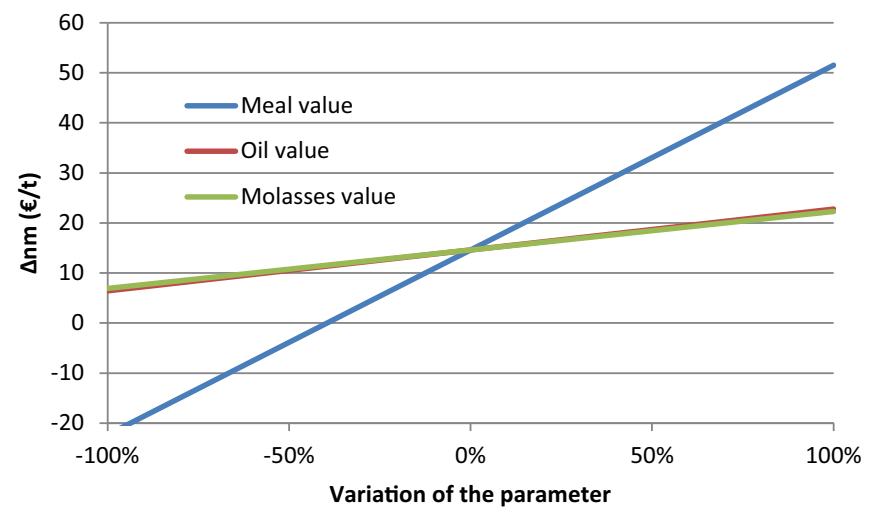

Fig. 3. Sensitivity of $\Delta \mathrm{nm}$ to the valuation of the products.

profitability of the process provided the cost assessment is accurate.

\subsection{Uncertainty in the oil losses}

Concerning the oil recovery, our study did not include a long-duration trial in a real continuous extraction situation. Our estimations of the oil recovery are therefore not based on experimental data. The recovery of the oil left in the lean miscella needs to be observed over a long duration, because it is possible that enrichment of the solvent with polar lipids will increase the neutral oil retention in the solvent. Hence, more oil would go toward the molasses and the meals. To plot Figure 4, we started from the observation that our theoretical scheme predicted a negative difference of $8 \mathrm{~kg}$ of oil per ton for the hot ethanol process, knowing that $13 \mathrm{~kg}$ goes to the molasses offset by $5 \mathrm{~kg}$ taken from the cake. We then postulated that the losses could range from $50 \%$ of our base assumption to $200 \%$, i.e., values between 4 and $24 \mathrm{~kg} / \mathrm{t}$. The non-recovered oil is allocated $32 \%$ to the cake and $68 \%$ to the 


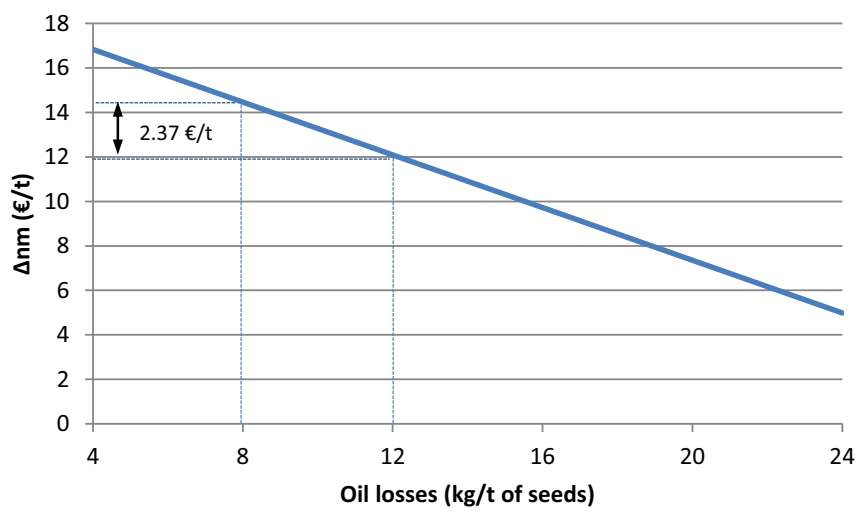

Fig. 4. Sensitivity of $\Delta \mathrm{nm}$ to oil losses.

molasses. The impact of these losses is far from negligible, since we can see that an increase of $50 \%$ in these losses makes us lose $2.4 € / t$ of seed.

\section{Conclusion}

The feasibility of the hot ethanol extraction process seems to meet our expectations.

However, we must remember that the hypotheses advanced here are based only on a laboratory experiment, which can do no better than approximate the performance of a continuous counter-current system. We have seen that the profitability of the set-up requires perfect control of the oil losses, and strongly depends on the selling price of the cake. Uncertainty in the costs of the process remains substantial.

These results are an incentive to continue experiments on a pilot scale in conditions closer to the actual process in order to validate the estimated material balances, and solve the questions related to the grinding of the seeds to obtain the required particle size distribution. Experiments will also be needed to carry out nutritional tests on cakes that will ensure the price levels necessary for the process to be economically viable.

In conclusion, using ethanol to replace hexane leads to higher crushing costs, but these costs could be offset by a higher value of the meal in the case of rapeseed. This possibility is of importance in an oilseed sector strongly affected by change of policy concerning biodiesel in Europe.

Acknowledgements. This work was made possible by funds provided by the French Agency for Research (ANR / ALID 13): the authors are grateful for this support. Terres Inovia and SAIPOL were also supporting this project and the authors thank them for both technical and financial contributions.

\section{References}

Blin J, Brunschwig C, Chapuis A, et al. 2013. Characteristics of vegetable oils for use as fuel in stationary diesel engines - toward specifications for a standard in West Africa. Renew Sustain Energy Rev 22: 580-597.

Carré P. 2012. Recovery of low temperature heat in oil mills. OCL 19 (6): 324-331.

Chemat F, Vian M, Cravotto G. 2012. Green extraction of natural products: concept and principles. Int J Mol Sci 13(7): 8615-8627.

Cheng M-H., Rosentrater KA. 2017. Economic feasibility analysis of soybean oil production by hexane extraction. Ind Crop Prod 108: 775-785.

Doyon M, Bergeron S. 2015. Analyse du comportement des consommateurs québécois vis-à-vis le paiement d'une prime pour des oeufs de poules logées dans un environnement amélioré. s.1. : CIRANO, 2015. 2015rp-20.

Hron RJ, Koltun SP, Graci AV. 1982. Biorenewable solvents for vegetable oil extraction. J American Oil Chem Soc 59(9): 674A684A.

Linnet L. 2012. Hot ethanol extraction of lipids from plant or animal materials. s.1. : Patent application, 2012. WO2014053180A1.

Loh HP, Lyons J, White III CW. 2002. Process equipment cost estimation, final report (No. DOE/NETL-2002/1169). Pittsburgh, PA (US): National Energy Technology Lab.; Morgantown, WV (US): National Energy Technology Lab.

Noel B, Krapf G. 1986. Safety in loading and unloading operations. s. 1. : The American Oil Chemists Society., 1986. In: World Conference on Emerging Technologies in the Fats and Oils Industry: Proceedings (p. 78).

Pégase, Base de données. Observations et statistiques. Ministère de la Transition Écologique et Solidaire. [Online] http://developpe ment-durable.bsocom.fr/statistiques/ReportFolders/ReportFold ers.aspx?sRF_ActivePath $=$ P, 6831,6832,6848\&sRF_Mode $=$ 0\&sRF_Expanded $=, P, 6831,6832,6848$,.

RÈGLEMENT (CE) N $\mathrm{N}^{\circ} 889 / 2008$ DE LA COMMISSION. 2008. Portant modalités d'application du règlement (CE) n ${ }^{\circ} 834 / 2007$ $\mathrm{du}$ Conseil relatif à la production biologique et à l'étiquetage des produits biologiques en ce qui concerne la production biologique, l'étiquetage et les contrôles. s.1. : du 5 septembre 2008. (JO L 250 du 18.9.2008, p. 1).

Sneider L, Finkbeiner M. 2013. Life cycle assessment of EU oilseed crushing and vegetable oil refining. FEDIOL. Available from http://www.fediol.eu/data/Full\%20FEDIOL\%20LCA\% 20report_05062013_CR\%20statement.pdf.

Tavoularis G, Hébel P, Billmann M, et al. 2015. Comment a évolué sur les deux dernières décénies la relation à la qualité pour les consommateurs français. s.1. : CREDOC-Cahier de Recherche, 2015. n' 327 .

Terres Inovia. 2016. Qualité des tourteaux de colza. Terres Inovia. Disponible sur: http://www.terresinovia.fr/uploads/tx_cetiom lists/fiche_Terres_inovia_qual_tourteaux_colza2016_VF.pdf.

Turton R, Bailie RC, Whiting WB, et al. $20 \overline{1} 5$. Analysis, synthesis, and design of chemical processes, fourth edition. Boston: Prentice Hall, ISBN-13: 978-0-13-261812-0. 